\title{
Physical and chemical properties of drinking and usage waters of Mardin**
}

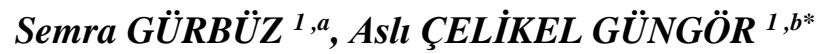 \\ ${ }^{1}$ Mardin Artuklu University, Tourism Faculty, Gastronomy and Culinary Arts Department, Mardin, Turkey. \\ ORCID: 0000-0003-0583-295X ${ }^{a}$; 0000-0002-7099-0308 ${ }^{b}$
}

\author{
MAKALE BILGISI / \\ ARTICLE \\ INFORMATION: \\ Geliş / Received: \\ 21 Kasım 18 \\ 21 November 18 \\ Kabul / Accepted: \\ 14 Mart 19 \\ 14 March 19 \\ Anahtar Sözcükler: \\ Fiziksel Özellik \\ Kimyasal Özellik \\ Mardin \\ $\mathrm{Su}$
}

Keywords:

Chemical Properties

Mardin

Physical Properties

Water

\begin{abstract}
:
This study aims to investigate the physical and chemical content of storage, well and network water used in Mardin and to evaluate it in terms of human health. In this study, 111 water samples were collected from Mardin, including 11 storage, 39 well and 61 network water were subjected to physical and chemical analysis. The taste and odor analyze of the samples were done organoleptically. The turbidity and color analyses were done by turbidimeter and nessler tupe respectively and the $\mathrm{pH}$ and electrical conductivity parameters of the samples were measured with the double channel digital multimeter. Ammonia, iron, chloride, calcium, magnesium and total hardness parameters of the waters were determined by spectrophotometer. It was determined that the taste, odor, ammonium, chloride and calcium values of the water samples were in compliance with the limits set by the Regulation on Water Intended for Human Consumption and TS 266. The $\mathrm{pH}$ value of $\% 0.9$ of water samples, turbidity and colour of $\% 0.9$ water samples, electrical conductivity of $\% 0.9$ water samples and iron value of \%23.42 of water samples did not comply with the Regulation on Water Intended for Human Consumption and TS 266. The magnesium amount of $\% 18.02$ water samples and total hardness value of $\% 8.10$ of water samples did not comply with TS 266. No statistically significant difference was found between the physical and chemical parameter values of the water samples collected from storage, well andnetwork $(\mathrm{P}>0.05)$. As indispensable for human life, It is recommended that water should be monitored continuously in terms of quality parameters in order to prevent health risks and prevent usage problems.
\end{abstract}

\section{Mardin içme ve kullanma sularının fiziksel ve kimyasal özellikleri \\ ÖZET:}

Bu çalışmada Mardin'de kullanılan depo, kuyu ve şebeke sularının fiziksel ve kimyasal içerikleri bakımından incelenmesi ve insan sağlığı yönünden değerlendirilmesi amaçlamıștır. Çalıșmada Mardin'den 11 depo suyu, 39 kuyu suyu ve 61 şebeke suyu olmak üzere 111 adet su örneği toplanmıştır. Örneklerinin tat ve koku analizleri organoleptik olarak bulanıklık ve renk analizleri sırasıyla turbidimetre ve nessler tüp ile, $\mathrm{pH}$ ve elektriksel iletkenlik parametreleri çift kanallı dijital multi metre, amonyum, demir, klorür, kalsiyum, magnezyum ve toplam sertlik parametreleri ise spektrofotometre ile tespit edilmiştir. Su örneklerinin tat, koku, amonyum, klorür ve kalsiyum değerlerinin İnsani Tüketim Amaçlı Sular Hakkında Yönetmelik ve TS 266 Standardında belirtilen limitlere uygun olduğu saptanmıştır. Örneklerin \%0.9'unun pH, \%0.9'unun bulanıklık ve renk, \%0.9'unun elektriksel iletkenlik, \%23.42'sinin demir değerlerinin İnsani Tüketim Amaçlı Sular Hakkında Yönetmelik ve TS 266'ya uygun olmadığı, \%18.02'sinin magnezyum değeri, \%8.10'unun ise toplam sertlik değerinin TS 266 'da belirtilen değerlere uygun olmadığı saptanmıştır. Analizi yapılan depo, kuyu ve şebeke suyu örneklerinin fiziksel ve kimyasal parametre değerleri arasında, istatistiksel olarak anlamlı bir fark tespit edilmemiştir $(\mathrm{p}>0.05)$. İnsan hayatı için vazgeçilmez öneme sahip olan suyun sağlık açısından risk oluşturmasının önlenmesi ve kullanım problemlerinin engellenmesi içinkalite parametreleriyönünden düzenli izlenmesi önerilmektedir.

How to cite this article: Gürbüz S, Güngör AÇ : Physical and chemical properties of drinking and usage waters of Mardin. Vet Hekim Der Derg, 90 (2): 76-82, 2019. DOI: $10.33188 /$ vetheder.48641

\footnotetext{
* Sorumlu yazar / Corresponding author e-posta adresi / e-mail address: acelikel2@gmail.com

**This research was presented as a poster presentation at the 2nd International Animal Food Congress.
} 


\section{Introduction}

Water is one of the most important elements required for life. Human needs an average of $2.5 \mathrm{~L}$ of water per day (1). The amount of water used in Turkey is approximately 44 billion $\mathrm{m}^{3} /$ year of which $72.72 \%$ is used in agricultural irrigation, $15.90 \%$ in drinking and usage waters and $11.36 \%$ in industry. The annual amount of water available per capita in Turkey is around $1,519 \mathrm{~m}^{3}(2)$. River and lake waters, which have been liquidated by various methods besides network water, well water and fountain water, used by people for drinking and personal needs are considered as potable water (3). Physical, chemical and microbiological properties of water may vary according to the source. Water, which is a highly beneficial substance for human health, may cause risks to human health since it can be easily contaminated for a variety of reasons or due to the high content of some organic substances such as ammonium and iron $(1,4)$.

As a result of the long term exposure of drinking water of which contaminated chemical substances, generally may ocur serious health problems. For the consumer, the water is wanted not only to be safe, but also to have acceptable taste, odor and appearance. Contamination with chemicals, although not in all cases, may cause unacceptable taste, odor and appearance in water and the water may become unusable. Guideline values have not been established for the factors affecting the water quality which do not have direct connections with negative health effects (5).

There are various regulations for determining the physical, chemical and microbiological quality of drinking and usage water. Some of these are, The Regulation on Water Intended for Human Consumption (RWIFHC), the European Union Directive of 98/83 the and TS 266 standard of the Turkish Standard Institute. The physical and chemical quality parameters determined for the water in these regulations are given in Table $1(6,7,8)$. The aim of this study was to investigate the physical and chemical content of the storage, well and network water used in Mardin province and to assess the risk of human health.

Table 1: Some quality parameters of water

Tablo 1:Suyun bazı kalite parametreleri

\begin{tabular}{|c|c|c|c|}
\hline Parametres & RWIFHC $^{*}$ & TS 266* & 98/83 EC \\
\hline Taste & $\begin{array}{l}\text { Acceptable to consumers and no } \\
\text { abnormal change }\end{array}$ & $\begin{array}{l}\text { No noticeable change in the unique } \\
\text { taste of water }\end{array}$ & $\begin{array}{l}\text { Acceptable to consumers and } \\
\text { no abnormal change }\end{array}$ \\
\hline Odor & $\begin{array}{l}\text { Acceptable to consumers and no } \\
\text { abnormal change }\end{array}$ & $\begin{array}{l}\text { No noticeable change in the unique } \\
\text { odor of water }\end{array}$ & $\begin{array}{l}\text { Acceptable to consumers and } \\
\text { no abnormal change }\end{array}$ \\
\hline Turbidity & $\begin{array}{l}\text { Acceptable to consumers and no } \\
\text { abnormal change }\end{array}$ & $5 \mathrm{NTU}^{* *}$ & $\begin{array}{l}\text { Acceptable to consumers and } \\
\text { no abnormal change }\end{array}$ \\
\hline Color & $\begin{array}{l}\text { Acceptable to consumers and no } \\
\text { abnormal change }\end{array}$ & $20 \mathrm{mg} / \mathrm{L}$ & $\begin{array}{l}\text { Acceptable to consumers and } \\
\text { no abnormal change }\end{array}$ \\
\hline $\mathrm{pH}$ & $\leq 9.5-6.5 \geq$ & $\leq 9.5-6.5 \geq$ & $\leq 9.5-6.5 \geq$ \\
\hline Electrical conductivity & $\leq 2500 \mu \mathrm{s} / \mathrm{cm}$ & $\leq 2500 \mu \mathrm{s} / \mathrm{cm}$ & $\leq 2500 \mu \mathrm{s} / \mathrm{cm}$ \\
\hline Ammonia & $\leq 0.5 \mathrm{mg} / \mathrm{L}$ & $\leq 0.5 \mathrm{mg} / \mathrm{L}$ & $\leq 0.5 \mathrm{mg} / \mathrm{L}$ \\
\hline İron & $\leq 200 \mu \mathrm{g} / \mathrm{L}$ & $\leq 200 \mu \mathrm{g} / \mathrm{L}$ & $\leq 200 \mu \mathrm{g} / \mathrm{L}$ \\
\hline Chloride & $\leq 250 \mathrm{mg} / \mathrm{L}$ & $\leq 600 \mathrm{mg} / \mathrm{L}$ & $\leq 250 \mathrm{mg} / \mathrm{L}$ \\
\hline Calcium & & $\leq 200 \mathrm{mg} / \mathrm{L}$ & \\
\hline Magnesium & & $\leq 50 \mathrm{mg} / \mathrm{L}$ & \\
\hline Total hardness & & $500 \mathrm{mg} \mathrm{CaCO} / \mathrm{L}^{* * *}$ & \\
\hline
\end{tabular}

*RWIFHC: The Regulation on Water Intended for Human Consumption. TS 266: TS 266 standard of the Turkish Standard Institute. EC98/83: The European Union Directive of 98/83.**NTU:Nefelometric Turbidity Unit.***Recommended value. 


\section{Material and Methods}

In this study, 111 water samples (11 storage water, 39 well water and 61 network water) were collected from Mardin between April-June 2018. Samples were brought to the laboratory in $250 \mathrm{ml}$ glass bottles and subjected to physical and chemical analysis.

Taste and odor analyzes were done organoleptically. Organoleptic analyzes were performed by a panelist group of 5 people who had previously experienced these analysis. Each water sample was tested for the presence of salt, bitter, sour and other flavors. Water samples were heated to $40{ }^{\circ} \mathrm{C}$ for odor analysis and tested for the presence of odors related to mold, ammonia, algae, swamps and rotten $(9,10)$. Taste and odor were scored by each panelist according to the determined scala varying from 1 to 5 (not noticed=1, light=2, medium=3, strong=4, very strong=5). Samples for color analysis were put into nessler tube and compared with the standard water samples found in the nesstler tubes $(6,8)$. Turbidity test were done by turbidimeter (Hach, TU5200) and $\mathrm{pH}$ and electrical conductivity were measured by dual channel digital multimeter (Hach, HQ440D). Ammonia, iron, chloride, calcium, magnesium and total hardness parameters of waters were measured by spectrophotometer (Hach, DR 3900) according to manufacturer's instructions using LCK 304, LCK 321, LCK 311, LCK 326 test kits, respectively

\section{Assessment of the results}

Calcium, magnesium and total hardness values determined as a result of the analysis were evaluated according to the limits specified in TS 266 standard of Turkish Standards Institution (6) and other parameters were evaluated according to limits stated in the RWIFHC (8) (Table 1).

\section{Statistical analysis}

Statistical analysis of the data was performed by SPSS ver. 21 program. The difference between physical and chemical parameter values of storage, well and network water samples was analysed using Analyses of Variance (ANOVA) test. $\mathrm{p}<0.05$ was considered as statistically significant.

\section{Results}

Physicochemical analysis results of the water samples are given in Table 2 . The analysis results were determined between for $\mathrm{pH}$ values 6.24-8.33, for conductivity values 39.50-2660.00 S/cm, for ammonium amounts 0.00-0.13 mg/L, for iron amounts $0.00-540.00 \mathrm{mg} / \mathrm{L}$, for chloride amounts $0.00-99.00 \mathrm{mg} / \mathrm{L}$, for calcium amounts $12.60-158.00 \mathrm{mg} / \mathrm{L}$, for magnesium amounts $4.00-163.00 \mathrm{mg} / \mathrm{L}$ and for hardness values $90.00-895.00 \mathrm{CaCO}_{3} \mathrm{mg} / \mathrm{L}$.

As a result of the analyses, it was determined that the taste, odor, ammonium, chloride and calcium values of the water samples were in compliance with RWIFHC and TS 266. pH of 1 network water, turbidity and color of 1 well water, electrical conductivity of 1 network water, Fe of 26 (3 storage water, 11 well water, 12 network water) water samples were not comply with the limits specified in the RWIFHC and TS 266. Magnesium of 20 (4 storage, 4 well, 12 network water) and 9 ( 3 wells, 6 water) water samples for total hardness were not comply with TS 266.

No statistically significant difference was found between the physical and chemical parameter values of, storage, welland network water samples $(\mathrm{P}>0.05)$ (Table 2)

\section{Discussion and Conclusion}

There should be no odors such as rotten, algae, mold, ammonia and swamp in drinking and usage waters and the waters should normally be clear, colorless and free of sediment (1). In the RWIFHC, it is stated that taste, odor, color and turbidity parameters of drinking and usage water should be acceptable to consumers and should not have any abnormal changes (Table 1). 
Table 2: Physical and chemical analysis results and of drinking and usage water

Tablo 2: İ̧me ve kullanma sularının fiziksel ve kimyasal analiz sonuçları

\begin{tabular}{|c|c|c|c|c|c|c|c|c|c|c|c|c|c|}
\hline \multirow[b]{2}{*}{ Parametres } & \multicolumn{4}{|c|}{ Storage water } & \multicolumn{4}{|c|}{ Well water } & \multicolumn{4}{|c|}{ Network water } & \multirow[b]{2}{*}{$\mathbf{p}$} \\
\hline & $\mathbf{n}$ & $\begin{array}{l}\mathbf{n}^{1} \\
(\%)\end{array}$ & $\begin{array}{l}\text { Min. } \\
\text { Max. }\end{array}$ & $\begin{array}{c}\text { Mean } \\
\pm \text { Sd. }\end{array}$ & $\mathbf{n}$ & $\begin{array}{l}\mathrm{n}^{1} \\
(\%)\end{array}$ & $\begin{array}{l}\text { Min. } \\
\text { Max. }\end{array}$ & $\begin{array}{c}\text { Mean } \\
\pm \text { Sd. }\end{array}$ & $\mathbf{n}$ & $\begin{array}{l}\mathbf{n}^{1} \\
(\%)\end{array}$ & $\begin{array}{l}\text { Min. } \\
\text { Max. }\end{array}$ & $\begin{array}{c}\text { Mean } \\
\pm \text { Sd. }\end{array}$ & \\
\hline Taste & 11 & $\begin{array}{c}0 \\
(0 \%)\end{array}$ & - & - & 39 & $\begin{array}{c}0 \\
(0 \%)\end{array}$ & - & - & 61 & $\begin{array}{c}0 \\
(0 \%)\end{array}$ & - & - & - \\
\hline Odour & 11 & $\begin{array}{c}0 \\
(0 \%)\end{array}$ & - & - & 39 & $\begin{array}{c}0 \\
(0 \%)\end{array}$ & - & - & 61 & $\begin{array}{c}0 \\
(0 \%)\end{array}$ & - & - & - \\
\hline Turbidity & 11 & $\begin{array}{c}0 \\
(0 \%)\end{array}$ & - & - & 39 & $\begin{array}{c}1 \\
(2.56 \%)\end{array}$ & - & - & 61 & $\begin{array}{c}0 \\
(0 \%)\end{array}$ & - & - & 0.401 \\
\hline Color & 11 & $\begin{array}{c}0 \\
(0 \%)\end{array}$ & - & - & 39 & $\begin{array}{c}1 \\
(2.56 \%)\end{array}$ & - & - & 61 & $\begin{array}{c}0 \\
(0 \%)\end{array}$ & - & - & 0.401 \\
\hline $\mathrm{Ph}$ & 11 & $\begin{array}{c}0 \\
(0 \%)\end{array}$ & $\begin{array}{l}7.30 \\
7.90\end{array}$ & $\begin{array}{c}7.58 \\
\pm 0.212\end{array}$ & 39 & $\begin{array}{c}0 \\
(0 \%)\end{array}$ & $\begin{array}{l}7.00 \\
8.22\end{array}$ & $\begin{array}{c}7.50 \\
\pm 0.284\end{array}$ & 61 & $\begin{array}{c}1 \\
(1.64 \%)\end{array}$ & $\begin{array}{l}6.24 \\
8.33\end{array}$ & $\begin{array}{c}7.50 \\
\pm 0.354\end{array}$ & 0.725 \\
\hline $\begin{array}{l}\text { Electrical } \\
\text { conductivity } \\
\mu \mathrm{s} / \mathrm{cm}\end{array}$ & 11 & $\begin{array}{c}0 \\
(0 \%)\end{array}$ & $\begin{array}{c}45.50 \\
1350.00\end{array}$ & $\begin{array}{c}732.31 \\
\pm 433.602\end{array}$ & 39 & $\begin{array}{c}0 \\
(0 \%)\end{array}$ & $\begin{array}{c}41.90 \\
2500.00\end{array}$ & $\begin{array}{c}721.49 \\
\pm 470.605\end{array}$ & 61 & $\begin{array}{c}1 \\
(1.64 \%)\end{array}$ & $\begin{array}{c}39.50 \\
2660.0 \\
0\end{array}$ & $\begin{array}{c}656.67 \\
\pm 455.391\end{array}$ & 0.751 \\
\hline $\begin{array}{l}\text { Ammonia } \\
\mathrm{mg} / \mathrm{L}\end{array}$ & 11 & $\begin{array}{c}0 \\
(0 \%)\end{array}$ & $\begin{array}{l}0.00 \\
0.06\end{array}$ & $\begin{array}{c}0.01 \\
\pm 0.017\end{array}$ & 39 & $0(0 \%)$ & $\begin{array}{l}0.00 \\
0.13\end{array}$ & $\begin{array}{c}0.03 \\
\pm 0.033\end{array}$ & 61 & $\begin{array}{c}0 \\
(0 \%)\end{array}$ & $\begin{array}{c}0.00 \\
0.9\end{array}$ & $\begin{array}{c}0.02 \\
\pm 0.030\end{array}$ & 0.152 \\
\hline Iron $\mu \mathrm{g} / \mathrm{L}$ & 11 & $\begin{array}{c}3 \\
(27.27 \%)\end{array}$ & $\begin{array}{c}22.00 \\
290.00\end{array}$ & $\begin{array}{c}154.45 \\
\pm 83.613\end{array}$ & 39 & $\begin{array}{c}11 \\
(28.21 \%)\end{array}$ & $\begin{array}{c}0.00 \\
540.00\end{array}$ & $\begin{array}{c}189.92 \\
\pm 137.376\end{array}$ & 61 & $\begin{array}{c}12 \\
(19.67 \%)\end{array}$ & $\begin{array}{c}0.00 \\
500.00\end{array}$ & $\begin{array}{c}161.70 \\
\pm 123.174\end{array}$ & 0.506 \\
\hline $\begin{array}{l}\text { Chloride } \\
\mathrm{mg} / \mathrm{L}\end{array}$ & 11 & $\begin{array}{c}0 \\
(0 \%)\end{array}$ & $\begin{array}{c}0.02 \\
94.00\end{array}$ & $\begin{array}{c}26.83 \\
\pm 24.820\end{array}$ & 39 & $\begin{array}{c}0 \\
(0 \%)\end{array}$ & $\begin{array}{c}0.01 \\
90.00\end{array}$ & $\begin{array}{c}32.23 \\
\pm 25.972\end{array}$ & 61 & $\begin{array}{c}0 \\
(0 \%)\end{array}$ & $\begin{array}{c}0.00 \\
99.00\end{array}$ & $\begin{array}{c}26.67 \\
\pm 27.173\end{array}$ & 0.590 \\
\hline $\begin{array}{l}\text { Calcium } \\
\mathrm{mg} / \mathrm{L}\end{array}$ & 11 & $\begin{array}{c}0 \\
(0 \%)\end{array}$ & $\begin{array}{c}53.05 \\
107.00\end{array}$ & $\begin{array}{c}82.22 \\
\pm 19.067\end{array}$ & 39 & $\begin{array}{c}0 \\
(0 \%)\end{array}$ & $\begin{array}{c}12.60 \\
145.00\end{array}$ & $\begin{array}{c}75.84 \\
\pm 29.893\end{array}$ & 61 & $\begin{array}{c}0 \\
(0 \%)\end{array}$ & $\begin{array}{c}28.00 \\
158.00\end{array}$ & $\begin{array}{c}83.67 \\
\pm 24.412\end{array}$ & 0.351 \\
\hline $\begin{array}{l}\text { Magnesium } \\
\mathrm{mg} / \mathrm{L}\end{array}$ & 11 & $\begin{array}{c}4 \\
(36.36 \%)\end{array}$ & $\begin{array}{l}27.00 \\
65.00\end{array}$ & $\begin{array}{c}46.60 \\
\pm 12.366\end{array}$ & 39 & $\begin{array}{c}4 \\
(10.26 \%)\end{array}$ & $\begin{array}{c}4.00 \\
163.00\end{array}$ & $\begin{array}{c}37.96 \\
\pm 26.152\end{array}$ & 61 & $\begin{array}{c}12 \\
(19.67 \%)\end{array}$ & $\begin{array}{c}10.70 \\
155.00\end{array}$ & $\begin{array}{c}40.04 \\
\pm 20.134\end{array}$ & 0.525 \\
\hline $\begin{array}{l}\text { Total } \\
\text { hardness } \\
\mathrm{CaCO}_{3} \mathrm{mg} / \mathrm{L}\end{array}$ & 11 & $\begin{array}{c}0 \\
(0 \%)\end{array}$ & $\begin{array}{l}250.00 \\
500.00\end{array}$ & $\begin{array}{c}378.84 \\
\pm 83.230\end{array}$ & 39 & $\begin{array}{c}3 \\
(7.69 \%)\end{array}$ & $\begin{array}{c}90.00 \\
880.00\end{array}$ & $\begin{array}{c}329.54 \\
\pm 141.805\end{array}$ & 61 & $\begin{array}{c}6 \\
(9.84 \%)\end{array}$ & $\begin{array}{l}200.00 \\
895.00\end{array}$ & $\begin{array}{c}367.35 \\
\pm 124.682\end{array}$ & 0.302 \\
\hline
\end{tabular}

n: number of samples, $n^{l}:$ number of unsuitable samples, Min: Minimum, Max: Maximum, Sd: Standard deviation

The taste and odor characteristics of the water samples collected from Mardin were determined to be in accordance with the RWIFHC and TS 266. It was determined that $1(0.9 \%)$ sample well water did not conform to the RWIFHC and TS 266 in terms of color and turbidity. Tuluk et al. (4), Cankaya et al. (11), and Ağaoğlu et al. (12), reported respectively that, 27 water samples collected in Erzurum, 36 water samples collected from Trabzon public fountains and 30 samples collected in Van region, complied with the regulation in terms of taste, smell, color and turbidity. Dönerci et al. (13) found that the spring waters studied in the Mediterranean and Central Anatolia regions were normal in terms of taste and odor, but $3.20 \%$ of the samples were turbid. The $\mathrm{pH}$ value of water is an important parameter in determining the hygienic quality of water $(1,14)$. The presence of calcium bicarbonate and alkali salts causes the water to be alkaline and the presence of carbon dioxide in the water causes the water to be acidic (15).

The World Health Organization has reported that excessive alkaline or excessive acidic waters may cause various human health problems (5). According to the RWIFHC, the $\mathrm{pH}$ values of drinking and usage water should be between 6.5-9.5.In our study, the mean value of $\mathrm{pH}$ levels of the samples taken in the storage, well and network waters was 7.58, 7.50 and 7.50, respectively. While 110 of the analyzed waters were in accordance with the RWIFHC and TS 266 in terms of $\mathrm{pH}$ value only one network water with ph 6.24 has been determined to be not suitable for the specified limits (Table 2).In some studies, the determined $\mathrm{pH}$ values were reported to be between 6.95 and 8.18 in spring waters (11), 5.22 to 8.27 in storage waters (5) and 5.27 to 8.53 in network waters (5). Kocak and Güner (16), doing research on drinking and usage waters in Erzurum, revealed that the average $\mathrm{pH}$ value in the wells, storage, indoor and fountain waters was 7.14, 7.24, 7.22 and 7.23, respectively. In a study, it was reported that the $\mathrm{pH}$ values of the public fountain waters in Trabzon ranged between 5.01 and 8.69 and two samples of network water were found to be below 6.5 (11).

Electrical conductivity can vary depending on the total amount of all anion and cation ions dissolved in water $(4,14)$. Electrical conductivity values increase when ion concentration increases in water (17). The average conductivity values of the samples were found to be $732.31 \mu \mathrm{S} / \mathrm{cm}$ in the storage water, $721.49 \mu \mathrm{S} / \mathrm{cm}$ in the well water and 565.67 
$\mu \mathrm{S} / \mathrm{cm}$ in the network water. The maximum electrical conductivity value of drinking and usage water should be 2500 $\mu \mathrm{S} / \mathrm{cm}$ (8) In this study, $1(0.9 \%)$ network water sample was found to be not suitable for the specified limits. In some other studies, the conductivity value of water has been reported to be between $25.9-195.5 \mu \mathrm{S} / \mathrm{cm}$ (13) in spring water and 232-260 $\mu \mathrm{S} / \mathrm{cm}$ in network water (4).

Ammonium concentrations in drinking water indicate a possible fecal contamination, which is a potential risk forhuman healt. (4). Ammonium can easily be converted to nitrate after nitrite by oxidation under appropriate reaction conditions. Nitrite can be associated with the deadly blue baby syndrome in infants, and also may cause synthesis of nitrosamines from carcinogenic substances by combining with amines and amides $(13,18)$. The average amount of ammonia in the storage, well and network waters was $0.01 \mathrm{mg} / \mathrm{L}, 0.03 \mathrm{mg} / \mathrm{L}$ and $0.02 \mathrm{mg} / \mathrm{L}$, respectively. This results found in this study was lower than the amount of ammonium reported by Tuluk et al. (4) (0.06 mg / L, - $0.19 \mathrm{mg} / \mathrm{L})$, whereas it was close to the amount of ammonium $(0.00 \mathrm{mg} / \mathrm{L}-0.03 \mathrm{mg} / \mathrm{L})$ and $(0.00 \mathrm{mg} / \mathrm{L}-0.04 \mathrm{mg} / \mathrm{L})$ reported by Cavus et al. (14) and Çankaya et al. (11) respectively.

Iron is one of the most common elements in the earth's crust and frequently seen in acidic waters. When iron forms compounds with magnesium and sulfur it is difficult to remove it from water. When the amount of iron in the water content exceeds $0.3 \mathrm{mg} / \mathrm{L}$, it creates reddish brown stains on the equipment and wall surfaces and changes the taste of water. This type of water is even not suitable to be used as a cleaning water (1). It was determined that 26 of the water samples collected from Mardin did not comply with the legal limits. The mean value of iron in the samples was $164.96 \mu \mathrm{g} / \mathrm{L}$. In a 2 year study carried out by Yelekçi et al. (19) it was found that the mean value of iron was 0.15 $\mathrm{mg} / \mathrm{L}$ in the first year and $0.19 \mathrm{mg} / \mathrm{L}$ in the second year. Yilmaz et al. (20) found that the amount of iron in bottle and network water was $4.94 \mu \mathrm{g} / \mathrm{L}$ and $19.12 \mu \mathrm{g} / \mathrm{L}$, respectively. The level of iron determined in our study was higher than Y1lmaz et. al (20) and similar with the values determined by Yelekçi et al. (19).

Chloride is an element that is commonly found in nature and it gives the water an corresive property when the amount of chloride is high in water (1). The average amount of chloride in the samples was found to be $26.83 \mathrm{mg} / \mathrm{L}$ in storage water, $32.23 \mathrm{mg} / \mathrm{L}$ in well water and $26.67 \mathrm{mg} / \mathrm{L}$ network water. The average amount of chloride in the waters investigated in some studies was reported to be $8.12 \mathrm{mg} / \mathrm{L}(21), 0.05 \mathrm{mg} / \mathrm{L}$ (14) and $34.10 \mathrm{mg} / \mathrm{L}$ (12). It is thought that the differences between the amount of chloride determined in water samples may be due to the proximity of the water source to the sea or salt deposits, the structure of the soil in the location of the water source and the factors such as animal waste, artificial fertilizer and waste water (21).

Calcium is beneficial for human health due to its many physiological properties. It can be mixed into water with dissolution of limestone by rain, groundwater and surface waters $(14,21)$. Due to the effect of calcium on hardening of water, it is not suitable for drinking and industrial use of water which contains large amounts of calcium (12). It is found that the average amount of calcium in the storage, well and network water was $82.22 \mathrm{mg} / \mathrm{L}, 75.84 \mathrm{mg} / \mathrm{L}$ and $83.67 \mathrm{mg} / \mathrm{L}$, respectively. In the other studies examining calcium in water, the average amount of calcium was reported to be $36.00 \mathrm{mg} / \mathrm{L}$ (14), $54.11 \mathrm{mg} / \mathrm{L} \mathrm{(20)}$ and $18.42 \mathrm{mg} / \mathrm{L}(21)$. The amount of calcium determined in this study was found to be higher than the studies of Çavuş et al. (14), Kılıç Altun et al. (22) and Alemdar et al. (21). It is thought that this finding may be related to soil structure in water source (12).

Magnesium can be mixed into water with dissolution of limestone and dolomites by stream, rain and groundwater. Magnesium can change the taste of water if the amount is high (21). It was determined that the mean value of magnesium in the analized storage, well and network water samples was $46.60 \mathrm{mg} / \mathrm{L}, 37.96 \mathrm{mg} / \mathrm{L}$ and 40.04 $\mathrm{mg} / \mathrm{L}$ respectively. Besides $36.36 \%, 11.11 \%$ and $19.67 \%$ of the analized storage, well and network water samples respectively, were above the limit of the Turkish Standard Institute TS 266 standard. In some studies, it was reported that the amount of magnesium was between $0.48 \mathrm{mg} / \mathrm{L}$ to $17.28 \mathrm{mg} / \mathrm{L}(12)$ in the spring water and $6.78 \mathrm{mg} / \mathrm{L}$ to 6.81 $\mathrm{mg} / \mathrm{L}(23)$ in drinking water. Çavuş et al. (14) found the average amount of magnesium in drinking water in Van was $22.00 \mathrm{mg} / \mathrm{L}$ and one of the analyzed sample was not in conformity with the TS 266 standard. The amount of magnesium in water may vary according to the structure of the soil and the new contamination of industrial waste to water (12).

Hardness is an important parameter for drinking water and water used in various areas of industry. The hardness of the water is mainly due to the dissolved calcium or magnesium salts and is considered to be the soap precipitation capacity (1). Various ratings are used to determine the hardness level of water in the world. According to 
these ratings, the waters are classified as very soft, soft, light hard, hard, very hard, very extreme hard. In Turkey, the hardness of water is generally expressed in $\mathrm{CaCO}_{3} \mathrm{mg} / \mathrm{L}$ or French hardness value $\left({ }^{\circ} \mathrm{F}\right)$. The use of hard water is not preferred because of the hardening of the skin, causing undesirable taste in the food, causing clogging of the equipment and making the cleaning process difficult. Excess of carbon dioxide in very soft waters increases the abrasion effect of these waters. These type of water causes abrasion of heavy metals like lead, tin and cadmium, that could be found in equipments, and dissolve into water (1). The mean hardness values in samples of storage, well and network water were $378.84 \mathrm{CaCO}_{3} \mathrm{mg} / \mathrm{L}\left(37.88{ }^{\circ} \mathrm{F}\right), 329.54 \mathrm{CaCO}_{3} \mathrm{mg} / \mathrm{L}\left(32.95{ }^{\circ} \mathrm{F}\right)$ and $367.35 \mathrm{CaCO}_{3} \mathrm{mg} / \mathrm{L}\left(36.73{ }^{\circ} \mathrm{F}\right)$, respectively. It was determined that 3 of the well water samples and 6 of the network water samples analyzed were above the recommended value in the TS 266 standard. Koçak and Güner (16) found that the average hardness values of water used in Erzurum were $9.59^{\circ} \mathrm{F}$ in well waters, $7.74{ }^{\circ} \mathrm{F}$ in storage waters, $8.32{ }^{\circ} \mathrm{F}$ in fountain waters and $7.96{ }^{\circ} \mathrm{F}$ in network waters. Çavuş et al. (14) found that the hardness values of Van drinking water were between $105.60 \mathrm{CaCO}_{3}$ $\mathrm{mg} / \mathrm{L}$ and $296.00 \mathrm{CaCO}_{3} \mathrm{mg} / \mathrm{L}$ (mean $181.20 \mathrm{CaCO}_{3} \mathrm{mg} / \mathrm{L}$ ). Ağaoğlu et al. (12) reported an average hardness of analyzed spring waters is $17.6^{\circ} \mathrm{F}$. It is believed that the differences between water hardness values that found in the researches are due to the differences in the amount of magnesium and calcium salts dissolved in water, the structure of the soil and the mixing of industrial wastes into water (12).

As a result, it was determined that some physical and chemicalparameters of drinking and usage water in Mardin province do not comply with limits set by regulation and standard. Therefore, it is recommended to continuously monitor the quality parameters of the water resources available in the province. The findings of this study will provide a basis for future studies.

\section{References}

1. Ağaoğlu S, Ekici K, Alemdar S, Dede S (1999): Van ve yöresi kaynak sularının mikrobiyolojik, fiziksel ve kimyasal kaliteleri üzerine araştırmalar. Van Tıp Derg, 6(2), 30-33.

2. Alemdar S, Kahraman T, Ağaoğlu S, Alişarlı M (2009): Bitlis ili içme sularının bazı mikrobiyolojik ve fizikokimyasal özellikleri. Ekoloji, 19(73), 29-38.

3. Atasoy N, Mercan U, Alacabey İ, Kul AR (2011): Van şehir merkezindeki içme ve musluk suyunda bulunan ağır metaller ve bazı makro element seviyeleri. Hacettepe J Biol \& Chem, 39 (4), 391-396.

4. Council Directive (1998): Official Journal of the European Communities. Council Directive 98/83/EC of 3November 1998. On the quality of water intended for human consumption. L 330,41, 5 December 1998, p: 32.

5. Çankaya S, Topbaş M, Yavuzyılmaz A, Yeşilbaş-Üçüncü Ş, Karakullukçu S, Kolaylı CC, Dilaver İ, Acar G, Parlak B, Şahin K, Hamzaoğlu K, Bölükbaş C, Çan G, Beyhun, NE (2017): Trabzon halk çeşmelerinin fiziksel, kimyasal, mikrobiyolojik yönden değerlendirilmesi. Türk Hij Den BiyolDerg, 74 (1), 21-28.

6. Çavuş A, Atıcı AA, Şen F (2017): Van-merkez içme sularının su kalite kriterlerinin incelenmesi. YYÜ Tar Bil Derg,27 (3), 326-336.

7. Dönderici ZS, Dönderici A, Başarı F (2010): Kaynak sularının fiziksel ve kimyasal kaliteleri üzerine bir araştırma. Türk Hij Den Biyol Derg, 67 (4), 167-172.

8. DSİ (2018): http://www.dsi.gov.tr/toprak-ve-su-kaynaklar1. Erişim tarihi:14/10/2018.

9. Kayaardı S (2015): Glda Hijyeni ve Sanitasyon. Sidas Yayınevi 7. Bask1, İzmir.

10. Kılıç Altun S, Paksoy N, Dinç H (2017): The investigation of physicochemical parameters of drinking and ground waters in Şanliurfa and Adlyaman. TURJOEM, 2-1 (3), 377-382.

11. Koçak Ö, Güner A (2009): Erzurum Il merkezindeki içme ve kullanma sularının kimyasal, fiziksel ve mikrobiyolojik kalitesi. Atatürk Üniv Vet Bil Derg,4 (1), 9-22.

12. Kuruma H, Poetzschke J (2002): İ̧̧me sularında amonyum iyonlarının uzaklaştırılmasında membran filtrasyon uygulaması. Ekoloji, 11 (42), 45-48.

13. MEGEP (2012): Kimya Teknolojisi: Sularda Fiziksel Kontroller,Millî Eğitim Bakanlığı,Ankara.

14. MEGEP (2012): Glda Teknolojisi: Duyusal Test Teknikleri,Millî Eğitim Bakanlığı,Ankara.

15. Örgev C, İnanç İ (2004): Doğal zeolit'in doğal kaynak sularında pH, iletkenlik ve sertlik özelliklerinin 
düzenleyicisi olarak kullanımı. BİYOMUT, 256-257.

16. RWIFHC (2005): T.C. Sağlık Bakanlığı İnsani Tüketim Amaçlı Sular Hakkında Yönetmelik Resmi Gazete Tarihi: 17.02.2005 Resmi Gazete Sayıs1: 25730.

17. Taşpınar B (2016): Salarha havzası akarsularında evsel atık sulardan dolayı oluşabilecek bakteriyolojik ve deterjan kökenli kirliliğin araştırılmast. Recep Tayyip Erdoğan Üniversitesi Fen Bilimleri Enstitüsü Yüksek Lisans Tezi Su Ürünleri Anabilim Dalı Rize, s.75.

18. Tayar M, Korkmaz NH, Özkeleş HE (2017): Beslenme İlkeleri. Dora Yayınevi 4. Baskı, Bursa.

19. TSE (2005): TS 266 Sular-İnsani Tüketim Amaçlı Sular. Türk Standartları Enstitüsü, 29 Nisan 2005.

20. Tuluk B, Kayserili OF, Kaşali K (2017): Erzurum ili şebeke sularının fiziksel, kimyasal ve mikrobiyolojik kaliteleri üzerine bir araştırma. J Turgut Ozal Med Cent,24 (1), 25-30. DOI: 10.5455/jtomc.2016.08.088

21. WHO (2011): Guidelines for drinking-water quality - 4th ed. Geneva.

22. Yelekçi S, Acemioğlu B, Avcı H (2012): Kilis il merkezi içme sularının kullanılabilirliğinin araştırılması. BİBAD, 5 (2), 77-81.

23. Yılmaz M, Bolu F, Mayda AS, Poyraz B (2017): Düzce'de satılan şişe suları ile musluk sularının ağır metal düzeylerinin incelenmesi. Konuralp Tıp Derg, 9 (1), 24-29. 